Sains Malaysiana 49(9)(2020): 2141-2148

http://dx.doi.org/10.17576/jsm-2020-4909-12

\title{
Lignin-Coated Polystyrene/Trichloromethylsilane Absorbent for Oil Spill Cleanup
}

(Penyerap Polistirena/Triklorometilsilana Bersalut Lignin untuk Pembersihan Tumpahan Minyak)

\author{
Nur Amalina AzHar, NAdia Adrus, Wan Aizan Wan RaHMAn \& RoHAh A. MaJiD*
}

\begin{abstract}
The study was conducted to determine the effectiveness of lignin-polystyrene/ trichloromethylsilane (TL-PS) absorbent in removing oil spillage from wastewater. Lignin powder obtained from the delignification of oil palm empty fruit bunch (OPEFB) was coated with PS emulsion (PSE) at various concentrations $(2,4,6, \& 8 \mathrm{~mL})$ in order to bind the powder into an aggregated form. Later, L-PS was exposed to trichloromethylsilane (TCMS) via chemical vapour deposition method (CVD) at fixed 7.5 min exposure time to form TL-PS absorbent. The wettability of TL-PS was determined by conducting water contact angle (WCA) measurement and oil sorption capacity. It was found that TL-PS4 sample (immersed in 8 $m L P S E)$ had the highest WCA value $\left(134.10^{\circ}\right.$ ) and oil sorption capacity (52\%) in comparison with L-PS4 (immersed in $8 \mathrm{~mL}$ PSE without TCMS) with WCA value of $99.10^{\circ}$ and oil sorption capacity of $40 \%$. Meanwhile, the disappearance of hydroxyl group (OH) at peak $3429 \mathrm{~cm}^{-1}$ and appearance of siloxane bonds (R-Si-O) at peak in range of 1000 $1100 \mathrm{~cm}^{-1}$ and 3.9 - $4.0 \mathrm{ppm}$ had confirmed the substitution occurred between these groups, as shown by the spectra obtained from attenuated total reflectance-Fourier transform infrared (ATR-FTIR) and nuclear magnetic resonance (NMR). Thermal stability of TL-PS4 (onset degradation temperature at $252^{\circ} \mathrm{C}$ ) was higher when compared with lignin (onset degradation temperature at $40^{\circ} \mathrm{C}$ ), as showed by the thermogravimetric analysis (TGA). Meanwhile, the surface of absorbent had change from smooth (L-PS4) to rough (TL-PS4) corresponding to the deposition of silane particles onto the surface of L-PS after the exposure with TCMS, as shown by the scanning electron microscopy (SEM). The results suggested that TL-PS has a promising potential to be used as an absorbent for oil spill cleanup.
\end{abstract}

Keywords: Chemical vapour deposition; lignin; oil spillage; polystyrene; trichloromethylsilane

\section{ABSTRAK}

Kajian ini telah dijalankan untuk menentukan keberkesanan serapan lignin-polistirena/triklorometilsilana (TL-PS) dalam mengasingkan tumpahan minyak daripada sisa air buangan. Serbuk lignin yang diperoleh daripada proses nyahlignin tandan kosong kelapa sawit (OPEFB) telah disalut dengan emulsi PS (PSE) pada kepekatan yang berlainan (2, $4,6 \& 8 \mathrm{~mL}$ ) untuk mengikat serbuk ke dalam bentuk bergumpal. Kemudian, L-PS didedahkan kepada triklorometilsilana (TCMS) melalui kaedah pemendapan wap kimia (CVD) pada masa yang ditetapkan iaitu 7.5 minit waktu pendedahan bagi menghasilkan penyerap TL-PS. Tahap pembasahan TL-PS telah ditentukan dengan menggunakan pengukuran sudut permukaan air (WCA) dan peratusan kapasiti penyerapan minyak. Bahan sampel TL-PS4 (yang direndam di dalam $8 \mathrm{~mL}$ PSE) menunjukkan nilai WCA yang tertinggi $\left(134.10^{\circ}\right)$ dan peratusan kapasiti minyak penyerapan meningkat kepada kira-kira 52\% berbanding dengan L-PS4 (direndam dalam 8 mL PSE tanpa TCMS) dengan nilai WCA bersamaan $99.10^{\circ}$ dan kapasiti penyerapan minyak pada $40 \%$. Sementara itu, penyingkiran kumpulan hidrosil (OH) pada puncak $3429 \mathrm{~cm}^{-1}$ dan kehadiran ikatan siloksana (R-Si-O) pada puncak dalam lingkungan 1000 - 1100 $\mathrm{cm}^{-1}$ dan 3.9 - 4.0 ppm mengesahkan penggantian telah berlaku antara kumpulan ini, seperti yang ditunjukkan oleh spektra analisis spektroskopi inframerah (ATR-FTIR) dan resonans magnetik nuklear (NMR). Kestabilan TL-PS terhadap suhu (suhu permulaan degradasi pada $252.41^{\circ} \mathrm{C}$ ) adalah lebih tinggi apabila dibandingkan dengan lignin (suhu permulaan degradasi pada $40^{\circ} \mathrm{C}$ ), seperti yang ditunjukkan oleh analisis haba gravimetrik (TGA). Sementara itu, permukaan penyerap telah bertukar dari permukaan yang licin (L-PS4) kepada permukaan yang kasar (TL-PS) sepadan dengan pemendapan zarah silina ke permukaan L-PS selepas terdedah kepada TCMS, seperti yang ditunjukkan oleh mikroskop pengimbasan elektron (SEM). Keputusan ini mencadangkan bahawa TL-PS berpotensi untuk digunakan sebagai penyerap bagi pembersihan tumpahan minyak.

Kata kunci: Lignin; polisterina; teknik pemendapan wap kimia; triklorometilsilina; tumpahan minyak 


\section{INTRODUCTION}

Water contamination with oil spillage is considered as a crucial concern for environmental safety. Most of the hydrocarbon compounds that floating on the water surface are threatening consequences and toxicity to human respiratory system, skin and eye irritation, marine life, and ecosystem health (Yi et al. 2011). A continuous increase in water vehicles during transportation, global industrial effluents (food industries, petrochemicals, textiles, steels) and human activities are the major factors which lead to catastrophic disasters to the oceans and environmental pollution (Doshi et al. 2018; Gupta et al. 2004). Large accidents occurred in Gulf Coast Mexico in 2010, and Exxon-Voldez oil spill in 1989 are examples of oil spillages that have badly affected the marine ecology (Michel \& Fingas 2016; Yuan et al. 2018; Zhang et al. 2018). Many methods and technologies are utilized to deal with the issues of oil spillages in water including in-situ burning, chemical dispersants, mechanical skimming and manual labour (Liu et al. 2019). However, these methods give a long term effect, non-environmental friendly and costly (Babiker et al. 2019; Liu et al. 2019).

Another technique to control the oil spillage is by using absorbents. They are made of natural absorbents (such as peat moss, sawdust, and clay) or the synthetic materials (such as polypropylene). Absorbents are widely used to remove the final traces of oil on shoreline or? in areas that cannot be reached by other clean-up techniques.

The use of agro waste- or biomass-based absorbents coupled with low surface tension materials such as silane- or silicone-based compounds have attracted many attentions due to their higher oil sorption capacities and also biomasses are renewable environmental friendly resources and cheap (Liu et al. 2014; Pour et al. 2019; Wang et al. 2012). For examples, Babiker et al. (2019) had prepared a superhydrophobic methylcellulose/poly(acrylic acid) coated with trichloromethylsilane (TCMS) absorbent via chemical vapour deposition (VCD) method. Liu et al. (2014) had fabricated a superhydrophobic/superoleophilic cotton-tetrarthoxysilane coated with silicone dioxide $\left(\mathrm{SiO}_{2}\right)$ nanoparticle absorbent via a sol-gel process. Wang et al. (2012) had successfully prepared a superhydrophobic/ oleophilic kapok fibre/silica nanoparticles modified with dodecyltrimethoxysilane (DTMS) oil sorbent. Among the abundant and cheap natural biomassess, lignin that derived from cellulosic biofuel or papermaking industries has the potential to be used as an absorbent. Lignin is an amorphous polyaromatic polyol which consists of precursor inter-unit linkages that have potential to react with other materials (Figure 1).

Kai et al. (2015) had developed a series of poly(ethylene glycol) methyl ether methacrylate (PEGMA)grafted-lignin hyper-branched copolymer for a smart biomaterial for biomedical application. Meanwhile, Ghavidel et al. (2019) had prepared Kraft lignin-PS absorbent via free radical polymerization for copper ions adsorption.

In our previous work, a hydrophobic/oleophilic lignin treated with TCMS (Li-TCMS) oil sorption via VCD method had been successfully prepared (Azhar et al. 2019). It was found that Li-TCMS absorbent has improved the oil sorption percentages compared with the untreated lignin. The reason is due to the hydroxyl groups (OH) of lignin has been replaced by the silane groups of TCMS, thus increasing the hydrophobic/oleophilic nature of Li-TCMS absorbent. However, since the Li-TCMS is in a powder/loose form, it tends to scatter in water rather than stay in the aggregated form. Hence, to overcome this drawback, we have made some modifications by coating the lignin first with polystyrene (PS) before subsequently deposited with TCMS through the VCD technique. PS was selected as a binder because it possesses a hydrophobicoleophilic property, owing to the presence of benzene ring in its molecular structure. A study by Li et al. (2014) had grafted styrene onto dealkaline lignin has been achieved successfully and the chemical reaction as Figure 1. Yang et al. (2017) had coated kapok fibre with PS resin and found that the oil sorption capacity had increased compared to the kapok alone. Furthermore, it showed good buoyancy on the water surface and good reusability in oil/water separation cycle. Hence, for our work, we used PS emulsion (PSE) instead of PS resin because it is an eco-friendly binder with low volatile organic compound (VOC) and it easily coats the surface of lignin since it is a water based system.

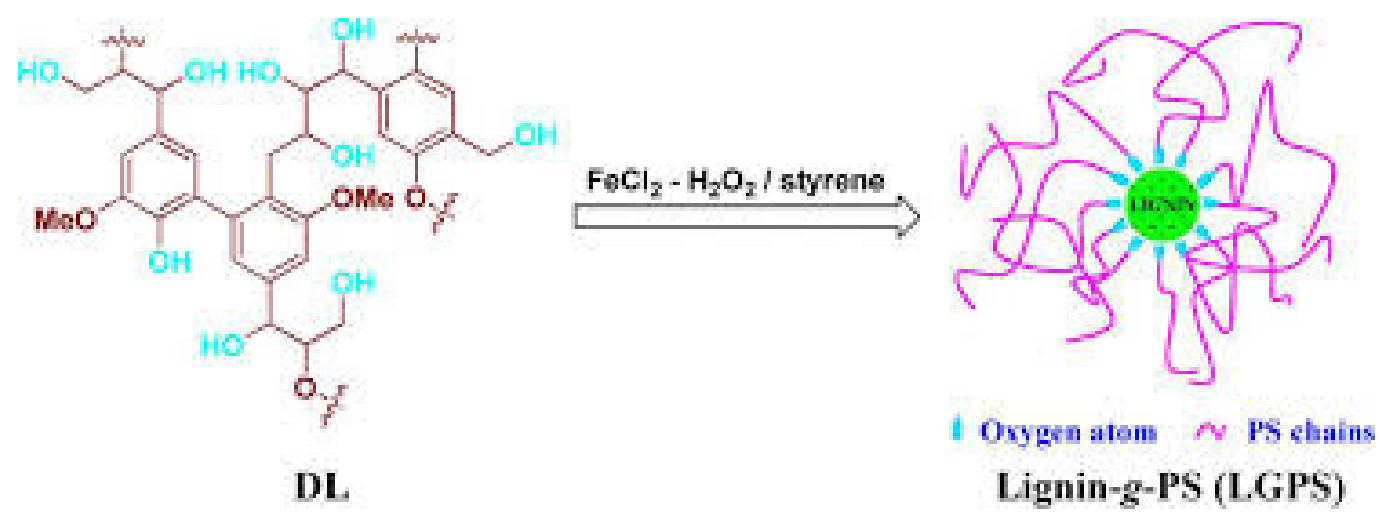

FIGURE 1. Illustration of lignin grafted PS copolymer (Li et al. 2014) 


\section{MATERIALS}

Lignin was obtained from the delignification of oil palm empty fruit bunch (OPEFB) using sodium hydroxide $(\mathrm{NaOH})$ and sulphuric acid $\left(\mathrm{H}_{2} \mathrm{SO}_{4}\right)$ purchased from Merck Sdn. Bhd. OPEFB was collected from oil palm plantation in Mersing, Johor. Polystyrene emulsion (PL 1292) was provided by Synthomer Sdn. Bhd. Tetrachloromethylsilane (TCMS) was bought from Sigma Aldrich and distilled water was obtained from Biopolymer laboratory, UTM.

\section{PREPARATION OF LIGNIN-POLYSTYRENE/TCMS ABSORBENT DELIGNIFICATION OF OPEFB}

About $80 \mathrm{~g}$ of OPEFBs were cooked in a diluted $10 \%$ w/v of sodium hydroxide $(\mathrm{NaOH})$ solution at $80{ }^{\circ} \mathrm{C}$ for 2 h. The fibrous materials were strained through a strainer and a black liquor was collected. Later, about $10 \% \mathrm{w} / \mathrm{v}$ of sulphuric acid was slowly added into the black liquor to reach $\mathrm{pH} 3$. The liquor was filtered through a mesh cloth and the residue (lignin) was collected. The lignin was washed with copious amount of distilled water until it reached $\mathrm{pH}$ 7. The collected solid lignin was oven-dried overnight at $60^{\circ} \mathrm{C}$ and was kept in a desiccator for further use.

\section{LIGNIN COATED POLYSTYRENE EMULSION}

About $0.2 \mathrm{~g}$ of lignin was mixed with PS emulsion in a stainless steel container according to the formulations shown in Table 1. After $1 \mathrm{~min}$ of stirring, lignin-coated PS (L-PS) was dried in the oven at $60{ }^{\circ} \mathrm{C}$ until a constant weight was achieved.

\section{PREPARATION OF TL-PS ABSORBENT VIA CHEMICAL VAPOUR DEPOSITION METHOD}

A non-woven tea bag containing $2 \mathrm{~g}$ of L-PS was placed in a sealed flask filled with $12 \mathrm{~mL}$ of TCMS. The sealed flask was placed in oven at temperature of $60{ }^{\circ} \mathrm{C}$ for 7.5 min to allow the deposition of TCMS onto the L-PS surface. The silane groups in the TCMS vapour had replacing the hydroxyl groups $(\mathrm{OH})$ of lignin while releasing the hydrogen chloride ( $\mathrm{HCl})$. The obtained TL-PS was washed with distilled water to remove traces of $\mathrm{HCl}$ groups from the surface of the L-PS. The deposition technique was adopted from the works done by Azhar et al. (2019) and Tejado et al. (2014). The sample was dried in the oven overnight and was kept in desiccator for further characterizations.

TABLE 1. Formulation of TL-PS at fixed TCMS content and exposure time

\begin{tabular}{ccc}
\hline Sample code & Lignin $(\mathrm{g})$ & PS emulsion $(\mathrm{mL})$ \\
\hline TL-PS1 & 0.2 & 2 \\
TL-PS2 & 0.2 & 4 \\
TL-PS3 & 0.2 & 6 \\
TL-PS4 & 0.2 & 8 \\
\hline
\end{tabular}

\section{HYDROPHOBICITY, OLEO SORPTION CAPACITY AND REUSABILITY TEST OF TL-PS ABSORBENT}

The degree of hydrophobicity of TL-PS was determined using a water contact angle (WCA) measurement with a dynamic sessile drop technique. About $2 \mu \mathrm{L}$ of distilled water was dropped onto the sample using a micro-syringe at room temperature. An average of five readings of contact angle was taken from each sample. A digital camera was used to capture the droplet image. The angle value that $>90^{\circ}$ indicates a hydrophobic character (Cunha et al. 2010). Meanwhile, the oil-sorption capacities of lignin-coated PS/TCMS samples were measured. About $0.2 \mathrm{~g}$ sample was immersed into a cooking oil for $1 \mathrm{~min}$. The sample was taken out from the oil and was placed on the wire mesh to remove the excess oil. The oil sorption capacity $(\mathrm{Q})$ of the sample was calculated using
(1) (Oribayo et al. 2017). The reusability of the treated lignin-coated-PS was evaluated by repeating the sorption for 15 days.

$$
Q=\frac{M t-M i}{M i}
$$

where $Q$ is the oil sorption capacity of the sorbent; $M t$ is the weight of wet sorbent after draining $(\mathrm{g})$; and $M i$ is the initial weight of sorbent $(\mathrm{g})$.

\section{CHARACTERIZATIONS AND THERMAL STABILITY TEST OF TL-PS ABSORBENT}

The functional groups of uncoated lignin and TL-PS samples were identified by using an attenuated total reflectance-Fourier transform infrared (ATR-FTIR) model 
Shimadzu IR Tracer 100 at $4 \mathrm{~cm}^{-1}$ resolution, 32 scans and the wavenumbers ranging from 4000 to $500 \mathrm{~cm}^{-1}$ at room temperature. Further identification was conducted using a Bruker Advance/DMX 400 MHz NMR spectrometer with 16 scans for a proton nuclear magnetic resonance $\left({ }^{1} \mathrm{H}-\mathrm{NMR}\right)$ and a carbon proton nuclear magnetic resonance $\left({ }^{13} \mathrm{C}\right.$-NMR). About $100 \mathrm{mg}$ of lignin and TL-PS samples were dissolved in $500 \mu \mathrm{L}$ of DMSO and $\mathrm{CDCl}_{3}$, respectively. The thermal stabilities of samples were measured by using a Perkin Elmer TGA4000 thermogravimetric analysis (TGA) with a heating rate of $10{ }^{\circ} \mathrm{C} / \mathrm{min}$ from ambient temperature to $900{ }^{\circ} \mathrm{C}$ and under a nitrogen flow of $20 \mathrm{~mL} /$ min. For surface morphologies, the samples were analysed using a scanning electron microscope (SEM) model EMLEO SUPRA 35VP, where the cryo-fractured samples were coated with gold sputtering prior to examination.

\section{RESULTS AND DISCUSSION}

WATER CONTACT ANGLE MEASUREMENT HYDROPHOBIC AND OLEOPHILIC SURFACE

Results of WCAs for TL-PS samples are shown in Figure 3(a) and Table 2. It can be seen that WCA values increased with increasing PS volumes and all TL-PS samples had WCAs higher than of sample L-PS4 (without TCMS). These indicated that the presence of TCMS had increased the hydrophobic characters of samples. As a comparison, sample TL-PS4 exhibited the highest WCA of $134.10^{\circ}$ which was about $35 \%$ higher than that of sample L-PS4, although both samples were immersed in the same amount of PSE (i.e. $8 \mathrm{~mL}$ ). This can be explained as follows; silane groups of TCMS had replaced the hydroxyl groups of lignin, hence producing the silylated external and

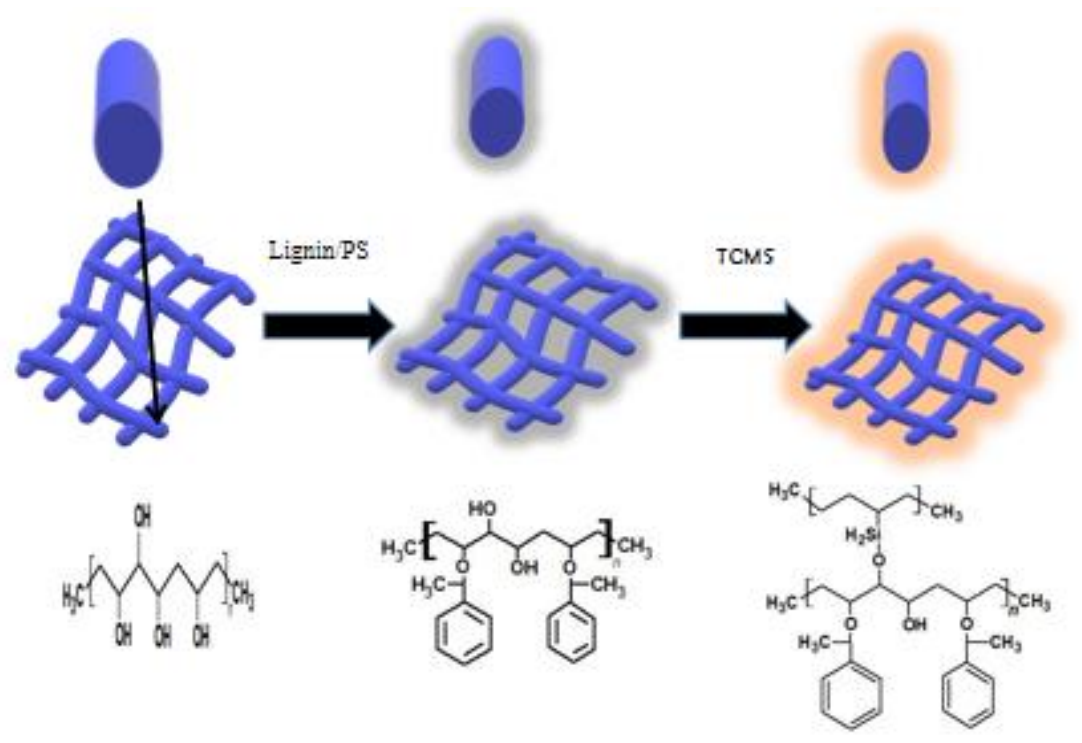

FIGURE 2. Schematic illustration of the fabrication processes of treated lignin-coated-PS

$\begin{aligned} \mathrm{Cl}_{3}-\mathrm{Si}_{-} \mathrm{CH}_{3}+\text { lignin-OH } \rightarrow & \text { lignin-O-SiCH3 }+\mathrm{HCl} \\ \text { TCMS } & \text { Silylated lignin } \quad \text { Hydrochloric acid }\end{aligned}$

SCHEME 1. Substitution between OH of lignin with hydrolysed silane of TCMS (Cunha et al. 2010) 
internal micropores surfaces of sample (Figure 2 and Scheme 1). The substitution between these hydrophilichydrophobic groups had made the TL-PS4 became more hydrophobic. The same findings were reported by Bogdan and Kulmala (2006) and Cunha et al. (2010).

However, since the amount of TCMS $(0.2 \mathrm{~g})$, the exposure time $(7.5 \mathrm{~min})$ and the coating period of ligninPSE ( $1 \mathrm{~min}$ ) were fixed for all samples, the only variable left was the amount of PSE used to coat the lignin. Higher PSE volume, meanings more PS available to coat the surface of the lignin, thus increasing its hydrophobicity. The explanations are as follows; PSE consists of the emulsified PS particles in water medium; hence, PSE can easily coat the surface of lignin due to the formation of hydrogen bonding between the $\mathrm{OH}$ groups of lignin and the $\mathrm{OH}$ groups of water. When the water evaporated, PS particles diffused and form continuous film that coated the surface of lignin. Since PS is a hydrophobic polymer, owing to the aromatic ring and the ethylene group in its molecular structure, PS can contribute to the increase of the hydrophobicity of TL-PS, as shown by the sessile drops in Figure 3(a). PS materials play an important role where it influences the wettability and amphiphilicity of the absorbents (Li et al. 2008; Vince et al. 2006; Wang et al. 2012).

Meanwhile, for the oil sorption capacity (Figure 3(a)), all samples were able to absorb the oil in the range of $40-52 \%$ in day 7 with relative to the day 0 . Sample TL-PS4 had the highest sorption capacity of $52 \%$ where no traces of oil seen left on the surfaces of water, as illustrated in Figure 4. After day 7, the sorption capacities of all samples started to decrease steadily, but still averagely higher than that of sample L-PS4. This was thought due to all samples had reach their saturation points as the pores in lignin cannot absorbed more oil. These results also reflected to the reusability of the samples that were repeated for 15 days and their efficiencies started to level-off starting at day 7. The findings are in agreement with other workers (Wang et al. 2013).

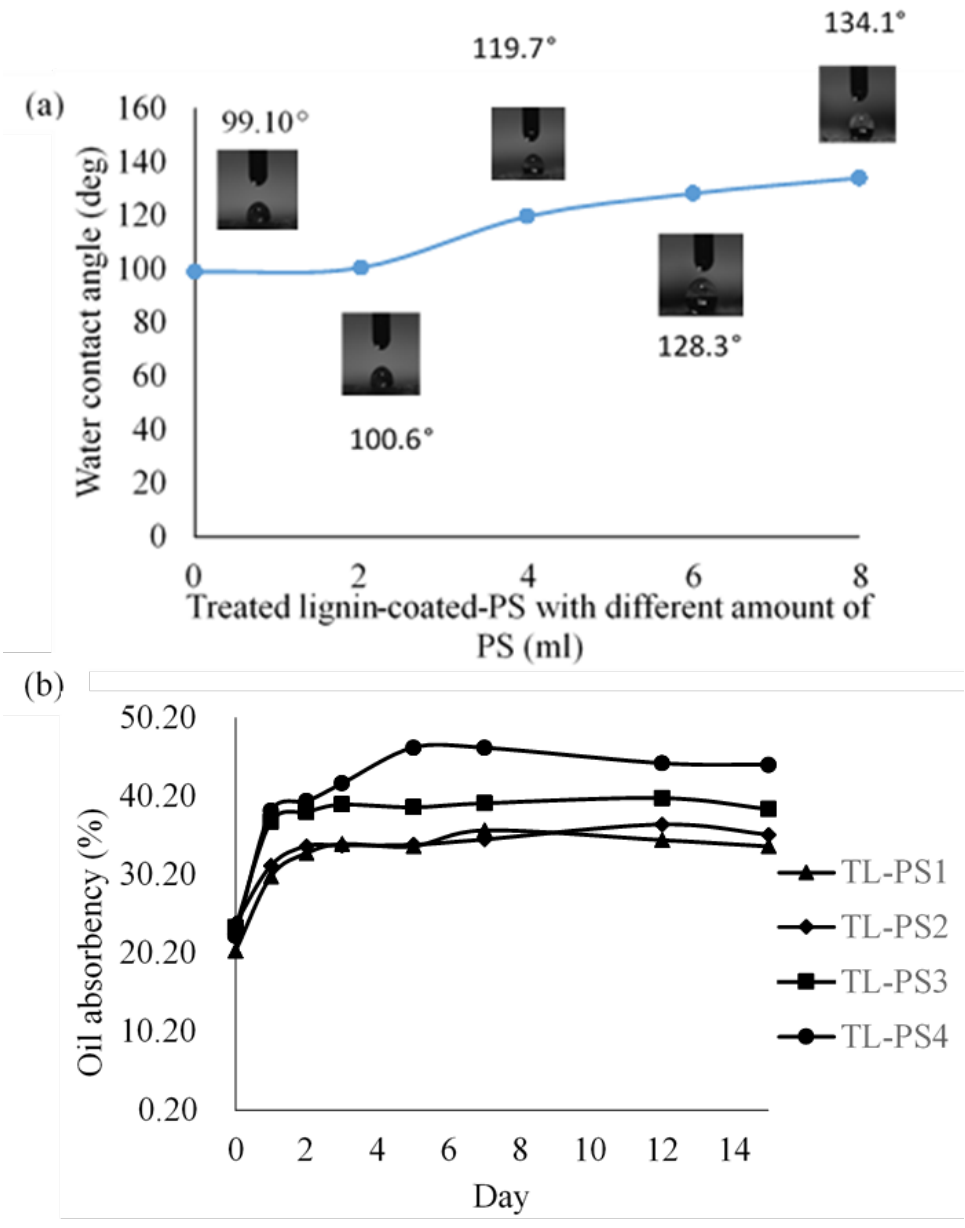

FIGURE 3. The results of (a) water contact angles and (b) oil absorption capacity for treated lignin-coated-PS samples 

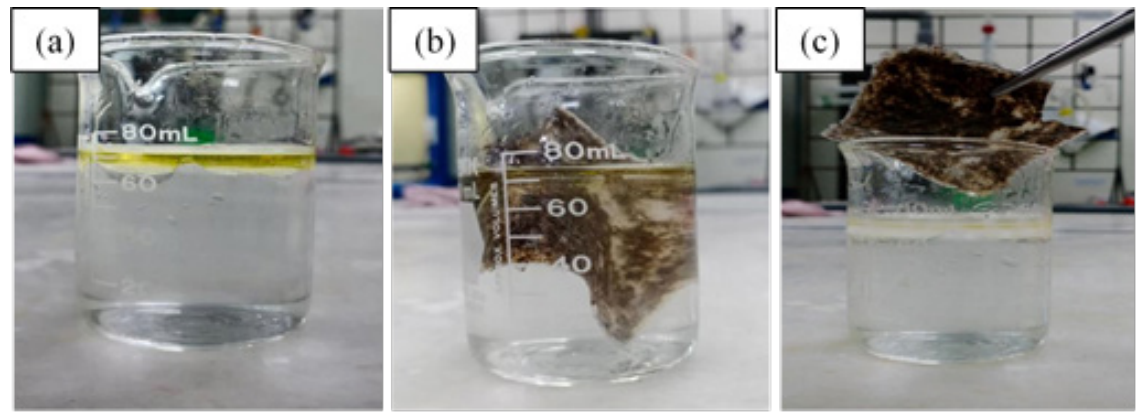

FIGURE 4. The illustration of oil clean-up by sample TL-PS4 (a) oil-water mixture before immersion (b) immersion of the sample into oil-water mixture for $1 \mathrm{~min}$ (0 day) and (c) no trace of oil layer left in day 7

The summaries of WCAs and oil sorption capacities of all samples are shown in Table 2.

TABLE 2. WCA and oil sorption capacity of TL-PS samples and L-PS4

\begin{tabular}{lccccccccc}
\hline \multirow{2}{*}{ Sample } & WCA(0) & \multicolumn{7}{c}{ Oil sorption capacity, $\%$} \\
\cline { 3 - 9 } & & $* 0$ day & 1 day & 2 day & 3 day & 5 day & 7 day & 12 day & 15 day \\
\hline L-PS4 & 99.10 & 20.11 & 28.82 & 28.31 & 32.69 & 33.60 & 33.76 & 33.88 & 34.08 \\
TL-PS1 & 100.60 & 20.49 & 30.00 & 32.93 & 34.09 & 33.80 & 35.85 & 34.61 & 33.80 \\
TL-PS2 & 119.70 & 24.00 & 31.38 & 33.85 & 33.92 & 34.02 & 34.69 & 36.60 & 35.30 \\
TL-PS3 & 128.30 & 23.50 & 36.99 & 38.19 & 39.12 & 38.78 & 39.30 & 39.96 & 38.56 \\
TL-PS4 & 134.10 & 22.39 & 38.34 & 39.56 & 41.83 & 46.40 & 46.39 & 44.41 & \\
\hline
\end{tabular}

*Immersion in oil-water mixture for $1 \mathrm{~min}$

\section{IDENTIFICATION OF THE FUNCTIONAL GROUPS OF TL-PS ABSORBENT}

The ATR-FTIR spectra of lignin, L-PS4 and TL-PS4 samples were shown in Figure 5. It can be seen that common peaks for lignin were observed at $3000-3500 \mathrm{~cm}^{-1}$ and 2800-2900 $\mathrm{cm}^{-1}$, corresponding to $-\mathrm{OH}$ stretching and $\mathrm{C}-\mathrm{H}$ vibration, respectively. Meanwhile, the detection of peaks at $1600-1650 \mathrm{~cm}^{-1}$ were attributed to the presence of $\mathrm{C}-\mathrm{C}$ stretching of the aromatic rings in lignin. Other works had also observed these peaks (Asim et al. 2015; Zhang et al. 2017).

For sample L-PS4, the intensity of the -OH groups were reduced, and the peak was shifted to the right (from 3498 to $3429 \mathrm{~cm}^{-1}$ ), indicating the formation of bonded -OH groups. This supported the explanations on the formation of hydrogen bonding between $\mathrm{OH}$ groups of lignin and $\mathrm{OH}$ groups of water of PES. In addition, a strong band was detected at $780 \mathrm{~cm}^{-1}$, attributed to the monosubstituted aromatic nuclei of PS, as reported by other researchers (Ghavidel \& Fatehi 2019; Zhang et al. 2017). For sample TL-PS4, the OH-peak had disappeared due to the substitution with silane groups of TCMS, as detected at 1000-1100 $\mathrm{cm}^{-1}$, corresponded to the presence of weak shoulder peak of siloxane-based groups (i.e. Si-O-C and Si-O-Si) stretching bands (Wang et al. 2012). These peaks were overlapped with the large and intense lignin $\mathrm{C}-\mathrm{O}$ stretching bands at $1050 \mathrm{~cm}^{-1}$ (Azhar et al. 2019; Cappelletto et al. 2012; Yang et al. 2017). 


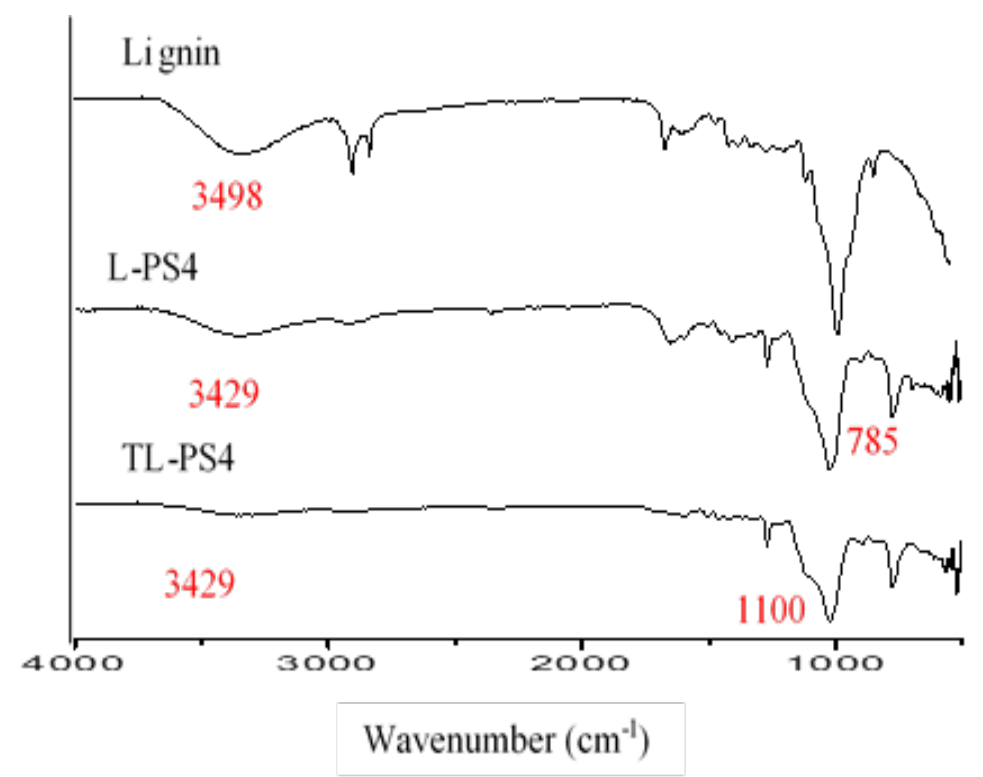

FIGURE 5. FTIR spectra of lignin, L-PS4 and TL-PS4

The chemical compositions of lignin and TL-PS4 were confirmed with the ${ }^{1} \mathrm{H}-\mathrm{NMR}$ spectra as shown in Figure 6(a). Wide and intense chemical shifts were observed in the region of $3.64 \mathrm{ppm}$ and $0-1.5 \mathrm{ppm}$ which corresponding to the methoxyl group and hydrocarbon chains of lignin, respectively. The hydroxyl groups were detected in the regions of 7.0-7.5 ppm. In the case of TL-PS4, the disappearance of hydroxyl peak and the appearance of siloxane bonds (-Si-O-R) as detected at 3.9-4.0 ppm was related to the removal of $\mathrm{OH}$ groups and the substitution of silane groups. Meanwhile, the chemical shifting at $0.5-2.5 \mathrm{ppm}$, was belong to aliphatic hydrogen of PS that coated the lignin, as reported by Li et al. (2015) and Wang et al. (2013). For ${ }^{13} \mathrm{C}-\mathrm{NMR}$ spectra in Figure 6(b), the detection of intense chemical shifting at $13.7 \mathrm{ppm}$ and $19.10 \mathrm{ppm}$ were attributed to the methoxyl groups of lignin that produced from the reaction between the carboxyl carbon of lignin and silane of TCMS (Anju \& Narayanankutty 2017; Salon et al. 2005).

The findings from FTIR and NMR supported the explanations on the increase of WCA and oil sorption capacity when lignin was coated with PSE and TCMS.

(a)

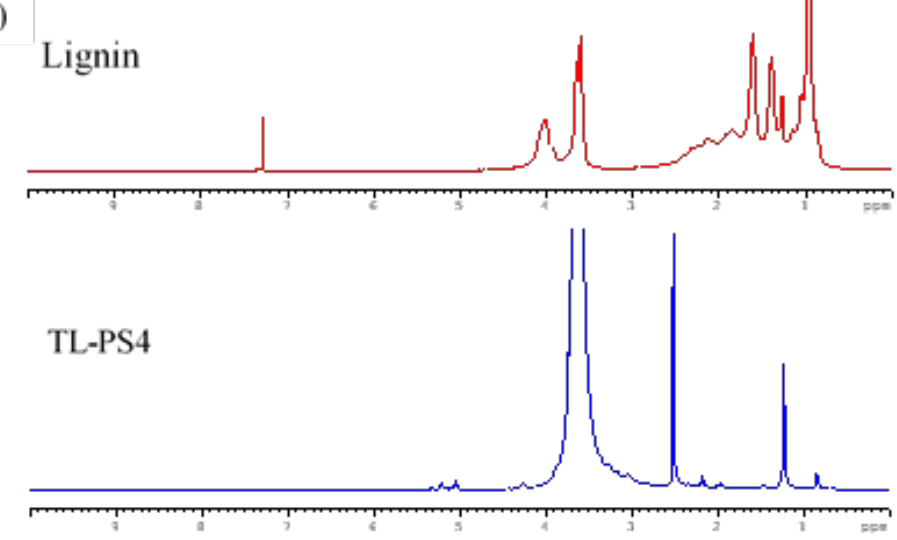




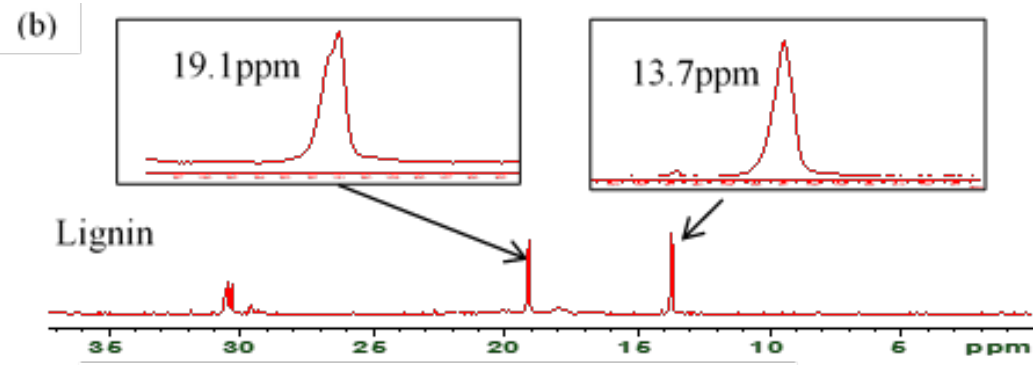

\section{TL-PS4}

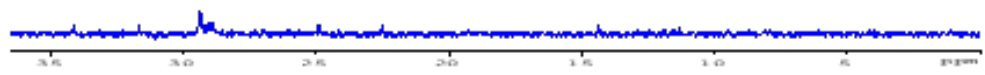

FIGURE 6. The results of (a) ${ }^{1} \mathrm{H}-\mathrm{NMR}$ spectroscopy and (b) ${ }^{13} \mathrm{C}-\mathrm{NMR}$ spectroscopy for lignin and TL-PS4

\section{THERMAL STABILITIES OF LIGNIN AND TL-PS4}

The plots of thermal stabilities of lignin and TL-PS4 were shown in Figure 6. There are three thermal decomposition steps observed for lignin and two decomposition steps for TL-PS4 during the heating process; lignin underwent the thermal degradation, starting from 30 to $141{ }^{\circ} \mathrm{C}$ with $7.08 \%$ weight loss, corresponding to the volatilization of water molecules contained in the sample. Further heating the lignin from 141 to $460{ }^{\circ} \mathrm{C}$ showed weight lost around $55.46 \%$, attributed to the elimination of water, carbon monoxide, carbon dioxide and methane. The third decomposition step occurred in the temperature ranges of 460 to $900{ }^{\circ} \mathrm{C}$ with about $24 \%$ weight loss, related to the pyrolytic degradation of the lignin backbone structure which released carbon dioxide, monomeric phenols and some aromatic rings into the vapour phase, as reported by Li et al. (2015). Meanwhile for TL-PS4, the first decomposition step occurred in the range of 30 to $430{ }^{\circ} \mathrm{C}$, which can be ascribed to the breakage of the short molecule such as styrene, together with other low molecular weight compounds from lignin such as water and carbon dioxide. As comparison, sample TL-PS4 showed higher thermal stability (onset temperature at $450{ }^{\circ} \mathrm{C}$ ) than lignin (onset temperature at $140^{\circ} \mathrm{C}$ ) which might be attributed to the silane particles structure in the absorbent. Further heating from 430 to $900{ }^{\circ} \mathrm{C}$ had shown a subtle degradation profile which related to the pyrolytic degradation of the lignin backbone structure. As comparison, at $900^{\circ} \mathrm{C}$, sample TL-PS4 had more weight loss $(7 \%)$ than lignin (13\%).

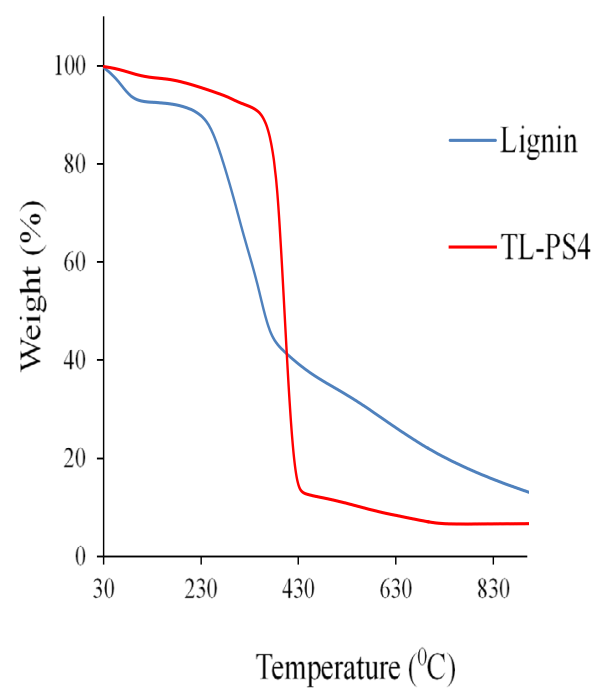

FIGURE 6. TGA spectra of lignin and TL-PS4 


\section{SURFACE MORPHOLOGY}

Surface morphologies of lignin, L-PS4 and TL-PS4 samples were illustrated in Figure 7(a)-7(c). It can be clearly seen that lignin showed a smooth surface of single fibril (Figure 7(a)). When lignin was immersed in PSE, the PS particles diffused with each other when water evaporated, thus forming a film on the surface of lignin (L-PS) as shown in Figure 7(b). This observation was consistent with the works reported by Ghavidel and
Fatehi (2019). As the L-PS was exposed to TCMS vapour, the siloxane of TCMS replaced the $\mathrm{OH}$ groups of lignin, thus forming the silane. The deposition of silane particles on the surface of lignin resulted rough surfaces as shown in Figure 7(c). The rough surface increased the surface area and oil retention ability, thus generating high oil sorption capacity. The latter finding supported the results from WCA and oil absorbent capacity of sample TL-PS4.
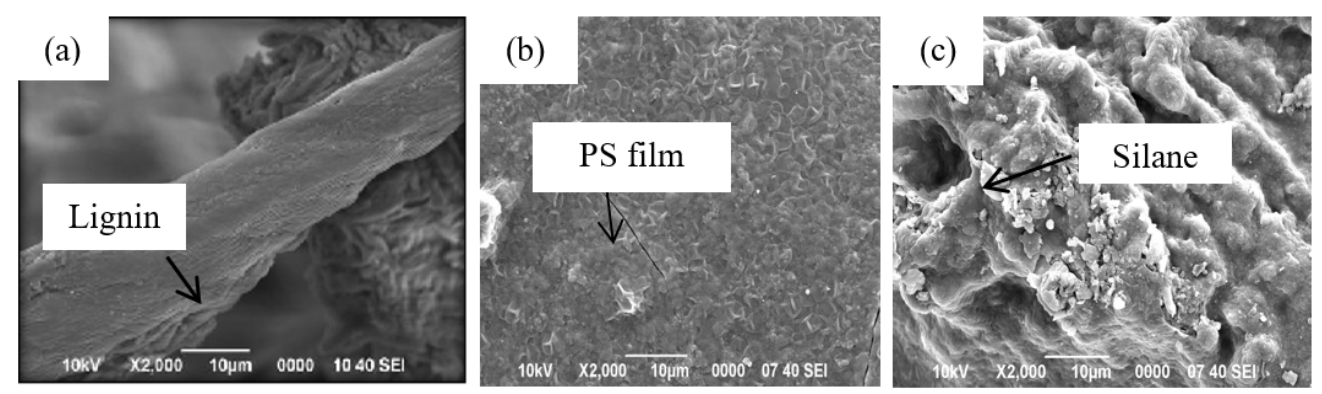

FIGURE 7. SEM micrographs of (a) lignin, (b) L-PS4 and (c) TL-PS4

\section{CONCLUSION}

Lignin-coated with PS/TCMS absorbent was successfully prepared by vapour deposition method (VCD). Results from ATR-FTIR and NMR had confirmed the reaction between $\mathrm{OH}$ groups of lignin and silane groups of TCMS with the disappearance of $\mathrm{OH}$ groups of lignin and the appearance of siloxane bonds (-Si-O-R) in TL-PS sample. The substitution between $\mathrm{OH}$ and silane had increased the WCA $\left(134.10^{\circ}\right)$ and the oil sorption capacity (52\%) of TL-PS4. High PSE volume used to coat the lignin was also contributed to the increase of both properties. In addition, sample TL-PS4 also showed high thermal stability on the temperatures ranging from 30 to $430{ }^{\circ} \mathrm{C}$. Beyond that, lignin had better thermal stability as shown by TGA. The deposition of silane particles on the surface of lignin had resulted rough surface as shown by SEM microimage. This rough surface provided large surface area and oil retention ability to the sample, thus increasing the oil sorption capacity. In conclusion, lignin-coated PS/TCMS has potential to be used as an absorbent for oil-spill clean-up.

\section{ACKNOWLEDGEMENTS}

The authors would like to express their appreciations for the financial support from Universiti Teknologi Malaysia for furbishing the grants to expedite the research work (GUP vot: Q.J130000.2546.14H38; UTMFR vot Q.J130000.2551.21H00).

\section{REFERENCES}

Anju, V.P. \& Narayanankutty, S.K. 2017. Impact of Bis-(3triethylsilylpropyl) tetrasulphide in the properties of PMMA/ cellulose composite. Polymer 119: 224-237.

Asim, M., Abdan, K., Jawaid, M., Nasir, M., Dashtizaleh, Z., Ishak, M.R. \& Hoque, M.E. 2015. A review on pineapple leaves fibre and its composites. International Journal of Polymer Science 2015(6): 1-16.

Azhar, N.A., Rahman, W.A.W. \& Majid, R.A. 2019. Lignintreated-trichloromethylsilane sorbent for oil spill cleanup. Journal of Energy and Safety Technology 1(2): 43-49.

Babiker, D.M.D., Zhu, L., Yagoub, H., Xu, X., Zhang, X., Shibraen, M.H.M.A. \& Yang, S. 2019. Hydrogen-bonded methylcellulose/poly(acrylic acid) complex membrane for oil-water separation. Surface \& Coatings Technology 367: 49-57.

Bogdan, A. \& Kulmala, M. 2006. Encyclopedia of Surface and Colloid Science. 2nd edition. New York: Taylor \& Francis.

Capelletto, E., Callone, E., Campostrini, R., Girardi, F., Maggini, S., Volpe, C.D., Siboni, S. \& Maggio, R.D. 2012. Hydrophobic siloxane paper coatings: The effect of increasing methyl substitution. Journal Sol-gel Science Technology. 62: 441-452.

Cunha, A.G., Freire, C., Sivestre, A., Neto, C.P., Gandini, A., Belgacem, M.N., Chaussy, D. \& Beneventi, D. 2010. Preparation of highly hydrophobic and lipophobic cellulose fibers by a straightforward gas-solid reaction. Journal Colloid and Interface Science 344(2): 588-595. 
Doshi, B., Sillanpää, M. \& Kalliola, S. 2018. A review of biobased materials for oil spill treatment. Water Research 135: 262-277.

Ghavidel, F. \& Fatehi, P. 2019. Synergistic effect of lignin incorporation into polystyrene for producing sustainable superadsorbent. RSC Advances 9: 17639-17652.

Gupta, R., Gupta, N. \& Rathi, P. 2004. Bacterial lipases: An overview of production, purification and biochemical properties. Application Microbiology Biotechnology 64(6): 763-781.

Kai, D., Low, Z., Liow, S.S., Karim, A.A., Ye, H., Jin, G., Li, K. \& Loh, X.J. 2015. Development of lignin supramolecular hydrogels with mechanically responsive and self-healing properties. ACS Sustainable Chemistry Engineering 3(9): 2160-2169.

Li, H., Zhang, Q., Gao, P. \& Wang, L. 2015. Preparation and characterization of graft copolymer from dealkaline lignin and styrene. Journal of Applied Polymer Science 132(17): 1-9.

Li, S.H., Zhang, S.B. \& Wang, X.H. 2008. Fabrication of superhydrophobic cellulose-based materials through a solution-immersion process. Langmuir 24(10): 5585-5590.

Liu, F., Ma, M., Zang, D., Gao, Z. \& Wang, C. 2014. Fabrication of superhydrophobic/superoleophilic cotton for application in the field of water/oil seperation. Carbohydrates Polymers 103: 480-487.

Liu, Y., Liu, N., Jing, Y., Jiang, Y., Yu, L. \& Yan, X. 2019. Surface design of durable and recyclable superhydrophobic materials for oil/water separation. Colloids and Surfaces A 567: 128-138.

Michel, J. \& Fingas, M. 2016. Oil spills: Causes, consequences, prevention and counter measure. In Fossil Fuels, edited Crawley, G.M. Singapore: World Scientific Publishing Company. pp. 159-201.

Oribayo, O., Feng, X., Rempel, G.L. \& Pan, Q. 2017. Synthesis of lignin-based polyurethane/graphene oxide foam and its application as an absorbent for oil spill clean-ups and recovery. Chemical Engineering Journal 323: 191-202.

Pour, F.Z., Karimi, H. \& Avargani, V.M. 2019. Preparation of a superhydrophobic and superoleophilic polyester textile by chemical vapor deposition of dichloromethylsilane for water-oil separation. Polyhedron 159: 54-63.

Salon, M.B., Abdelmouleh, M., Boufi, S., Belgacem, M.N. \& Gandini, A. 2005. Silane adsorption onto cellulose fibers: Hydrolysis and condensation reactions. Journal of Colloid and Interface Science 289(1): 249-261.

Tejado, A., Chen, W.C., Abim, M.N. \& van de Ven, T.G.M. 2014. Superhydrophobic foam-likecellulose made of hydrophobized cellulose fibres. Cellulose 21: 1735-1743.
Vince, J., Vilcknik, B.A., Fir, M., Vuk, A.S., Jovanovski, V. \& Simoncic, B. 2006. Structural and water-repellent properties of a urea/poly(dimethylsiloxane) sol-gel hybrid and its bonding to cotton fabric. Langmuir 22(15): 6489-6497.

Wang, J., Zheng, Y. \& Wang, A. 2013. Coated kapok fiber for removal of spilled oil. Marine Bulletin 69(1-2): 91-96.

Wang, J., Zheng, Y. \& Wang, A. 2012. Superhydropobic kapok fiber oil-absorbent: Preparation and high oil absorbency. Chemical Engineering Journal 213: 1-7.

Yang, J., Li, H., Lan, T., Peng, L., Cui, R. \& Yang, H. 2017. Preparation, characterization, and properties of fluorinefree superhydrophobic paper based on layer-by-layer assembly. Carbohydrate Polymers 178: 228-237.

Yi, Y., Yang, Z. \& Zhang, S. 2011. Ecological risk assessment of heavy metals in sodiment and human health risk assessment of heavy metals in fishes in the middle and lower reacher of the Yangtze River basin. Environmental Pollution 159(10): 2575-2585.

Yuan, J., Gao, R., Wang, Y., Cao, W., Dong, B. \& Dou, J. 2018. A novel hydrophobic adsorbent of electrospun $\mathrm{SiO}_{2} @ \mathrm{MUF}$ PAN nanofibrous membrane and its adsorption behaviour for oil and organic solvents. Journal Material Science 53: 16357-16370

Zhang, T., Li, Z., Lü, Y., Liu, Y., Yang, D., Li, Q. \& Qiu, F. 2018. Recent progress and future prospects of oil-absorbing materials. Chinese Journal of Chemical Engineering 27(6): 1282-1295.

Zhang, Z., Zhang, Y., Lin, Z., Mulyadi, A., Mu, W. \& Deng, Y. 2017. Butryric anhydride modified lignin and its oil-water interfacial properties. Chemical Engineering Science 165: 55-64.

Nur Amalina Azhar, Nadia Adrus \& Wan Aizan Wan Rahman School of Chemical and Energy Engineering

Universiti Teknologi Malaysia

81310 Skudai, Johor Darul Takzim

Malaysia

Rohah A. Majid*

Centre for Advanced Composite Materials

Universiti Teknologi Malaysia

81310 Skudai, Johor Darul Takzim

Malaysia

*Corresponding author; email: r-rohah@utm.my

Received: 16 January 2020

Accepted: 10 May 2020 